\title{
Commentary
}

\section{The changing mediascape in New Caledonia broadens the political spectrum}

\section{ABSIRACII}

Since the 1990s, the media landscape has broadened in New Caledonia, with new magazines and websites across the political spectrum. New Caledonia's FLNKS independence movement has long been supported by the community station Radio Djiido, which has expanded into live broadcasting and streaming on the web. But over the last decade, there has been an increase in opportunities for journalists to work with a range of new magazines, covering politics, culture, environment and economics. There is also increasing interest in the web among the young, with the beginning of internet blogging.

Keywords: blogging, Bwenando, community radio, Francophone media, internet, magazines, political journalism, Radio Djiido

\section{NIC MACLELLAN}

Freelance journalist and researcher, Melbourne

W

HETHER you are interested in mining or music, culture or cash crops, there is a proliferation of new media in New Caledonia, the French Pacific territory just 1800 kilometres off the coast of Queensland. While long established newspapers and radio stations still dominate the media market, a range of magazines and websites are providing opportunities for a new generation of journalists.

It is a sharp change from the 1980 s, when the French government broadcaster RFO and the daily newspaper Les Nouvelles Calédoniennes were the main source of news - and both were fiercely critical of New Caledonia's 
independence movement, the Front de Libération Nationale Kanak et Socialiste (FLNKS).

\section{Kaneka on the airwaves}

Between 1984 and 1988, there was conflict between supporters and opponents of independence, with armed clashes between the French military, antiindependence militias and the FLNKS.

New Caledonia's independence movement needed outlets to carry its message to supporters in the indigenous Kanak population. To challenge the dominance of conservative voices in the media, the FLNKS helped establish the community station Radio Djiido in 1985. Together with the magazine Bwenando, Djiido was the only outlet to provide alternative views to the anti-independence voices which dominated the airwaves.

Twenty four years on, Radio Djiido continues to broadcast around the clock, with news, talkback, feature interviews and music (Today, the station also streams online at www.radiodjiido.nc). The programming includes a heavy dose of kaneka - the fusion of reggae, rock and traditional Kanak rhythms that is wildly popular with young people around the country.

Lucienne Moréo-See has worked as a reporter and editor with the station for more than a decade: 'After all this time, Radio Djiido continues to serve the Kanak people, but now we also attract many listeners from the other communities' (interview, 18 October 2008).

I met Lucienne at Coula, a Kanak village on the east coast of New Caledonia's main island, as Radio Djiido prepared the live broadcast of a memorial concert for Kanak musician and broadcaster Jacques 'Kiki' Kare.

The Waa Wi Luu municipal council had organised the concert as a tribute to their local hero, who died in November 2007. Twenty hours of kaneka, more than 450 musicians and for those who cannot get to Coula, every moment is broadcast live by Radio Djiido. Djiido's Sandy Tyuiénon Irihau comperes the show, to celebrate the life of one of their earliest supporters-one of the founders of the kaneka music scene, Kiki Kare was a broadcaster with the French service of Radio Australia during the 1980s and a journalist with Djiido for many years.

For Lucienne Moréo-See, the media has an important role to carry Kanak culture to a wider audience: "We like to get out of the capital Noumea to organise these live broadcasts in the rural areas and outer islands, so the voices of ordinary people can be heard' (ibid.). 


\section{New magazines}

Since the 1998 Noumea Accord (a peace agreement between the French government and pro- and anti-independence leaders), the media landscape in New Caledonia has been transformed.

In the capital Noumea, you can go into any newsagency to find the full spectrum of magazines and papers from France, but also local productions like the weekly political review Les Infos, the satirical Chien Bleu or Environnement Nouvelle-Calédonie, which promotes green businesses and renewable energy.

The long-running cultural magazine Mwà Vée, produced from the Tjibaou Cultural Centre in Noumea, is now joined by glossies such as Palabre coutoumier, which profiles leading figures in the Kanak community and documents new initiatives to preserve and promote local languages, arts and music.

There are also new magazines that serve the Northern and Loyalty Islands Provinces, where the population is largely Kanak. From the women's magazine Pala Hin Hnémo to VKP Infos (which covers the booming mining towns of Voh, Kone and Pouembout), there are new publications that document the changes underway since the Noumea Accord.

\section{Serving the Northern Province}

Kanak journalist Marguerite 'Maguy' Poigoune works as a reporter with Le Pays (The Nation), the new monthly edited by Sonia Javert that covers the Northern Province. Maguy has returned from two years in France under the Cadre Avenir scheme - a training programme created after the Noumea Accord which expands vocational opportunities for young workers from New Caledonia. Formerly a broadcast journalist with Radio Djiido, Maguy moved to Toulouse to study print, TV and multi-media journalism. Returning to New Caledonia, she decided to relocate from the capital to Poindimie, the main east coast town in the Northern Province. Maguy says:

For me, it's great to work with Le Pays in the north, where the provincial government is working to build our independence. In the future, I hope to get into film-making and other media, so it's been really interesting to shift from radio to magazines. (M. Poigoune, personal communication, 16 October 2008)

At a time the country is focussed on economic development-with new nickel smelters under construction in the Northern and Southern 
provinces - there is still a thirst for cultural news, art and education. Even as the economy is being transformed, the provincial governments are working to promote Kanak culture for the majority of the population who still live in rural villages. For Patricia Goa, chair of the Northern Province's Cultural Commission, there is a vital role for the provincial administration to support cultural activities and new media:

We've been working to entrench new cultural infrastructure around the
province, to assist our people to make decisions on their future. As
well as the provincial cultural centres in Kone on the west coast and
Hienghene on the east coast, we're working to introduce libraries in
every tribe in the province to promote a culture of learning. We're also
setting up multi-media centres in every town, so that Kanak children in
the north will not be disadvantaged in this internet age (P. Goa, personal
communication, 20 October 2008).

\section{Blogs and websites}

As internet access spreads and bandwidth increases, more young people are using the web to talk culture and politics. In the lead up to the May 2009 elections for New Caledonia's three provincial Assemblies and national Congress, political parties started to use the web more effectively.

The better-resourced anti-independence parties have more capacity for web-based electoral campaigning. The most tech-savvy party is Avenir Ensemble (The Future Together) which sends out regular e-newsletters and runs debate forums on its website (www.avenirensemble.nc). The French Socialist Party runs its own blog for members in New Caledonia (pscaledonie. ouvaton.org).

But pro-independence groups have started to use the web as well. The FLNKS in the southern Province, after building a united electoral list, launched its own blog site to reach younger voters (www.iblogyou.fr/FLNKSUD). The Parti Travailliste - the newly created pro-independence Labour Party supported by the USTKE trade union confederation - also used the USTKE website to present profiles of leading candidates and the party's electoral manifesto (www.ustke.org/syndicat/).

One popular political blog is Caledosphere (www.caledosphere.com), which monitored the recent election campaign, responded to vigorous feedback from its readers, and provided a running election night commentary on the results as they came to hand. 
There is a way to go before the web replaces traditional media like newspapers, radio and TV as the main source of news, especially for people living in rural and outer island communities. But over the last decade, the media landscape has broadened in New Caledonia, with new media developing across the political spectrum. As people move into the final years of the Noumea Accord, with a referendum on New Caledonia's political status scheduled after 2014 , there are going to be lots of voices joining the debate.

Nic Maclellan works as a freelance journalist and researcher in the Pacific Islands. He is co-author of La France dans le Pacifique-de Bougainville à Moruroa (Editions La Découverte, Paris, 1992) and After Moruroa-France in the South Pacific (Ocean Press, 1998).

nicmaclellan@optusnet.com.au

\section{PACIFIC MEDIA CENTRE}

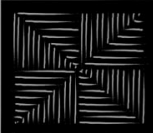

PAEIFIF MPE E I A LENTRE TE AMOKURA

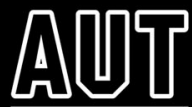

U N I VER S I T Y
The Pacific Media Centre (Te Amokura) is the only media research and community resource centre of its kind in Aotearoa/New Zealand and has a strategic focus on Māori, Pasifika and diversity media and community development:It was established by AUT University's Faculty of Design and Creative Technologies in 2007. having evolved from a cluster of research and community collaborations within the School of Communication Studies.

PMC activities include:

- International book and research publication

- Publication of the peer-reviewed Pacific Journalism Reviewresearch journal

- Publication of Pacific Media Centre Online as a media resource and postgraduate outlet

- Publication of Pacific Media Watch, a regional media monitoring service

- Journalism and media research opportunities

- Asia-Pacific internships for postgraduate students

www.pmc.aut.ac.nz | pmc国aut.ac.nz 